\title{
Tuntutan dan pengembangan studi islam di perguruan tinggi
}

\author{
Indah Maysela Azzahra a,1, ${ }^{*}$, Mahmud Arif a,2 \\ a UIN Sunan Kalijaga Yogyakata, Yogyakarta, Indonesia \\ *1 indahmayselaazzahra@gmail.com; ${ }^{2}$ marifnurch@yahoo.co.id
}

KA T A KU N C I
Tuntutan dan Pengembangan
Studi Islam
Perguruan Tinggi

Perguruan Tinggi

\section{KEYWORDS}

Demands and Development Islamic Studies College
Adapun tujuan penelitian ini yaitu untuk menjelaskan dan mengetahui makna studi Islam di perguruan tinggi, untuk menjelaskan dan mengetahui tuntutan studi Islam di perguruan tinggi, dan untuk menjelaskan dan mengetahui pengembangan studi Islam di perguruan tinggi. Metode penelitian ini digolongkan ke dalam jenis penelitian studi pustaka atau literature. Hasil penelitian menunjukkan bahwa perguruan tinggi yang paling kompleks dalam memberikan studi islam bagi masyarakat khususnya pada mahasiswa yaitu perguruan tinggi islam, seperti UIN/ IAIN/STAIN/STAIS. Setiap fakultas dan jurusan yang ada diperguruan ke-Islaman ini sudah menerapkan kajian-kajian ke-Islaman di samping dari mata kuliah wajib program studi. Pengenalan atau orientasi studi keislaman di perguruan tinggi Indonesia tidak hanya sebatas di negara Indonesia saja tetapi juga meneliti pada dunia Timur dan Barat. Pendekatan yang digunakan dalam mengkaji islam pada perguruan tinggi di Indonesia yaitu menggunakan lebih dari satu pendekatan yaitu menggunakan berbagai pendekatan seperti normative, historis, sosiologis, empiris, filosofis, Integratif, Interkonektif, fenomenologis, dan tipologis.

\section{The demands and development of Islamic studies in universities}

The purpose of this research is to explain and know the meaning of Islamic studies in universities, to explain and find out the demands of Islamic studies in universities, and to explain and know the development of Islamic studies in universities. This research method is classified into the type of literature study or literature. The results showed that the most complex universities in providing Islamic studies for the community, especially for students, were Islamic universities, such as UIN/IAIN/STAIN/STAIS. Every faculty and department in this Islamic school has implemented Islamic studies in addition to the compulsory courses of study programs. The introduction or orientation of Islamic studies in Indonesian universities is not only limited to Indonesian, but also examines the Eastern and Western worlds. The approach used in studying Islam at universities in Indonesian is using more than one approach, namely using various approaches such as normative, historical, sociological, empirical, philosophical, integrative, interconnected, phenomenological, and typological

This is an open-access article under the CC-BY-SA license. 


\section{Pendahuluan}

Perguruan tinggi adalah tujuan pendidikan bagi pemuda dan pemudi untuk menuntut ilmu yang lebih banyak lagi selepas Sekolah Menengah Atas (SMA). Orangorang berlombalomba mendaftarkan diri ke perguruan tinggi impian masing-masing. Sedangkan lembaga perguruan tinggi semaksimal mungkin dan semenarik mungkin harus dapat bersaing dengan sesama perguruan tinggi lainnya untuk memperoleh mahasiswa yang banyak juga berkualitas. Namun sebagai lembaga pendidikan terkadang hanya menjual tempat sekolah sebagai lembaga pendidikan bagi orangorang yang akan masuk ke perguruan tingginya. Namun ada juga lembaga pendidikan yang secara kompleks maksimal dalam penyediaan fasilitas, sumber daya guru, dan juga sumber daya ilmu dan materinya (Wardani, 2016).

Adapun perguruan tinggi yang termasuk ke dalam lembaga pendidikan dan perguruan tinggi yang kompleks dalam memberikan fasilitas dan materi bagi mahasiswa yaitu seperti perguruan tinggi islam. Perguruan tinggi islam baik negeri maupun swasta memiliki tujuan yaitu dapat mengkoneksikan ilmu pengetahuan alam, ilmu pengetahuan sosial, ilmu matematika, seni, dan ilmu ke-islaman yang secara komprehensif tercangkup dalam satu lembaga pendidikan saja.

Perguruan seperti UIN, IAIN, PTAIN, PTAIS, dapat menjadi salah satu tujuan para pemuda dan pemudi dalam menuntut ilmu dengan beragam jenis mata kuliah dengan mengkaitkan ilmu program studi dengan studi islam. Namun dengan adanya tuntutan masyarakat pada perguruan tinggi setiap tahunnya selalu hadir dan menghantui para tenaga kerja perguruan tinggi. Sehingga diharuskan untuk terus mengembangkan semua bidangnya terutama pada perguruan tinggi islam yang harus terus mengembangkan studi islam dalam program studi dan perguruan tingginya. Maka dari itu penulis melakukan kajian pustaka yang membahas tentang tuntutan dan pengembangan studi islam di perguruan tinggi. Adapun tujuan penulisan penelitian ini yaitu untuk menjelaskan dan mengetahui makna studi Islam di perguruan tinggi, untuk menjelaskan dan mengetahui tuntutan studi Islam di perguruan tinggi, dan untuk menjelaskan dan mengetahui pengembangan studi Islam di perguruan tinggi.

\section{Metode}

Penelitian ini digolongkan ke dalam jenis penelitian studi pustaka atau literature. Penelitian studi pustaka dilakukan dengan cara mengumpulkan data-data kajian yang relevan dengan penelitian ini. Pengumpulan data dilakukan dengan cara mengumpulkan data-data yang relevan dari buku-buku maupun jurnal dari internet. Setelah data terkumpul, selanjutnya akan dilakukan pengolahan data dengan menelaah dan mengkaji kemudian mendeskripsikan data serta membuat kesimpulan yang sesuai dengan tujuan penelitian.

\section{Hasil dan Pembahasan}

\section{Makna Studi Islam di Perguruan Tinggi}

Pada dasarnya, ada dua pendekatan untuk mempelajari Islam, baik dalam sumbersumber tekstual (Alquran dan hadis) atau ekspresi sosial dan budaya, yaitu pendekatan normatif dan historis. "Dialog" yang intensif dan terus-menerus antara keduanya dengan menerapan pendekatan Islamis dan barat yang terpadu dan kaya adalah suatu keharusan untuk mengatasi krisis intelektual dalam studi Islam di Indonesia dewasa ini. Dengan kata lain, Islam tidak boleh dilihat dari satu pendekatan saja, sehingga kita perlu membangun "jembatan" antara ilmu-ilmu agama Islam dan "sekuler" (ilmu alam, ilmu sosial, dan humaniora). Jembatan harus dua sisi, misalnya melalui "islamisasi ilmu pengetahuan" dan "scientifikasi Islam". Dengan langkah pertama, kita harus membuat ruang untuk tulisan suci 
dalam metode ilmiah,dan bahwa ilmu harus sarat nilai. Yang kedua berarti bahwa ilmu-ilmu agama Islam, seperti teologi, hukum, dan etika harus dipelajari dengan standar yang ilmiah .

Islam adalah banyak aspek (multiface) bukan semata representasi murni ajaran kitab suci al-Qur"an, melainkan ketika "diterjemahkan"(dipahami, dijabarkan, dimaknai) sebagai proses kesejarahan serta diterapkan oleh penganutnya dalam kehidupan pribadi dan masyarakat menjadi fenomena sosial kesejarahan yang beragam. Atas dasar ini, beberapa pengkaji Islam berupaya melakukan pembedaan "wajah-wajah" Islam tersebut. Pertama, Islam sebagai wahyu (ajaran yang bersumber dari Al-Qur"an dan as-sunnah) dan produk sejarah (pemahaman atas wahyu, konsepkonsep, dan aliran-aliran). Kedua, Islam normative (sebagai ajaran yang berisi normanorma, preskripsi-preskripsi, atau aturan-aturan yang mengikat) dan Islam historis (kesejarahan; pemahaman), sebuah titik-tolak yang harus dipahami, tegas Fazlur Rahman dalam Islam and Modernity, jika kita sepakat untuk melakukan "rekonstruksi sistematis" ilmu-ilmu keislaman, seperti teologi dan hukum. Ketiga, Islam sebagai doktrin (substansi keyakinan religius), Islam sebagai struktur dan dinamika masyarakat, dan keberagamaan (sikap anggota masyarakat dalam memaknai agamanya).

Diperguruan tinggi agama Islam, seperti UIN dan IAIN, keterlibatan maupun pembuatan jarak sesungguhnya adalah sama-sama penting. Hanya saja, pembuatan jarak (kemampuan mengkritisi) adalah problem yang hingga kini masih diderita. Faktor penyebab utama lemahnya kajian-kajian Islam dengan pendekatan yang lebih kaya dan sintetik serta objektif adalah karena kebanyakan peneliti muslim meneliti agamanya lebih banyak bertolak dari motivasi keagamaan (melanggengkan kemapanan keyakinan dan aliran yang dianut tanpa kritik). Padahal agama (termasuk Islam) adalah teks dan tradisi atau ide dan realitas yang, karenanya, tidak seharusnya dipandang sebagai keterlibatan saja, melainkan juga sikap netralis agar mampu melihat anomali-anomali atau penyimpangan-penyimpangan yang terjadi pada Islam dalam sejarah.

Keberadaan UIN/IAIN/STAIN/STAIS sebagai lembaga pendidikan tinggi yang berada di bawah lingkungan Kementrian Agama berfungsi sebagai sarana pengajaran agama Islam tingkat tinggi dan menjadi pusat pengembangan dan pendalaman ilmu pengetahuan agama Islam. Pada perkembangannya terutama untuk memenuhi tuntutan perubahan dan perkembangan zaman, UIN/IAIN/STAIN/STAIS diharapkan menjadi lembaga yang mampu menghasilkan para sarjana yang responsip terhadap tantangan zaman, dan kejadian-kejadian di dalam kehidupan bermasyarakat, serta diharapkan pula memiliki kualitas akdemis yang dapat diandalkan (Kurniasih, 2013).

Studi Islam di Perguruan Tinggi Islam di Timur Tengah lebih cenderung normatif dan ideologis terhadap Islam, karena kajian Islam di Timur Tengah bertitik tolak dari penerimaan terhadap Islam sebagai agama wahyu yang bersifat transenden. Sedangkan kecenderungan studi Islam di Indonesia ada dua macam antara lain; kecenderungan pertama, terjadinya pergeseran metode dari kajian-kajian Islam yang lebih bersifat normatif kepada yang lebih historis, sosiologis, dan empiris.

Kecenderungan kedua, orientasi keilmuwan yang lebih luas. Jika pada masa sebelumnya orientasi keilmuwan cenderung ke Timur Tengah, khususnya Universitas Al-Azhar, dalam dua dasawarsa terakhir kelihatan semakin luas dan beragam. Dalam konteks ini, model pendekatan Barat terhadap Islam mulai banyak bermunculan, yang pada pokoknya cenderung lebih bersifat historis dan sosiologis. Pendekatan normatif dalam kajian Islam menghasilkan pandangan serba idealistik terhadap Islam, yang pada gilirannya membuat kaum Muslimin melupakan atau meniscayakan realitas, karena itu, sering mengakibatkan mereka terjebak dalam "kepuasan batin" yang semu. Berkenaan dengan pendekatan normatif tersebut, Abudin Nata mengatakan bahwa aliran teologi yang satu begitu yakin dan fanatik bahwa pahamnyalah yang paling benar sedangkan paham yang lainnya salah, sehingga memandang paham orang lain tersebut keliru, sesat, kafir, murtad, dan seterusnya.

Sebaliknya pendekatan historis dan sosiologis membuka mata mahasiswa di lingkungan PTAI tentang realitas-realitas yang dihadapi Islam dan kaum Muslimin dalam perkembangan 
dan perubahan masyarakat. Pendekatan seperti ini mulai menemukan momentumnya dengan kembalinya sejumlah tamatan universitas Barat untuk mengajar di UIN, IAIN, STAIN, dll. Mereka kembali secara bergelombang, dimulai dengan generasi Mukti Ali dan Harun Nasution dan kemudian disusul kelompok tamatan Mc Gill University. Gelombang selanjutnya adalah mereka yang dikirim belajar ke beberapa universitas Amerika pada masa Menteri Agama, Munawir Sjadzali. Kendatipun orientasi studi Islam di Indonesia lebih cenderung ke Barat, studi di Timur Tengah tetap memiliki nilai penting, terutama dalam memahami aspek doktrinal, yang menjadi basis ilmu pengetahuan dalam Islam. Dengan demikian, orientasi studi islam di Timur dan Barat tetap signifikan dalam rangka pengembangan pendidikan Islam di lingkungan PTAI seluruh Indonesia. Hal ini menunjukkan bahwa studi Islam di PTAI di Indonesia tidak hanya beroreientasi ke Barat saja, tetapi juga ke Timur Tengah, yang dalam hal ini adalah Universitas Al-Azhar yang lebih menitik beratkan kajian keislaman secara normatif. Hal tersebut sesuai dengan pandangan Abudin Nata yang mengatakan bahwa bukan berarti kita tidah memerlukan pendekatan teologi dalam memahami agama, karena tanpa adanya pendekatan teologis, keagamaan seseorang akan mudah cair dan tidak jelas identitas dan pelembagaannya.

Lulusan pendidikan Islam kini dihadapkan pada tantangan, tuntutan, dan kebutuhan baru yang belum pernah ada sebelumnya. Sehingga perlu dilakukan pembaruan dan inovasi terhadap sistem, tata kelola, kurikulum, kompetensi sumber daya manusia, sarana dan prasarana, budaya, etos kerja, dan lain-lain. Jika tidak demikian, pendidikan Islam akan semakin tertinggal dan usang. Oleh karena itu, perlu dicari langkah-langkah kongkrit bagi pendidikan Islam agar mampu tetap bersaing di era disrupsi ini. Langkah solutifnya adalah dengan turut mendisrupsikan diri. Pendidikan Islam harus mau mendisrupsi diri jika ingin memperkuat eksistensinya. Bersikukuh dengan cara dan sistem lama dan menutup diri dari perkembangan dunia, akan semakin membuat pendidikan Islam kian terpuruk dan usang (obsolet). Maka dari itu, terdapat tiga hal yang harus diupayakan oleh pendidikan Islam, yaitu mengubah mindset lama yang terkungkung aturan birokratis, menjadi mindset disruptif (disruptive mindset) yang mengedepankan cara-cara yang korporatif.

Pendidikan Islam juga harus melakukan self-driving agar mampu melakukan inovasiinovasi sesuai dengan tuntutan era 4.0. Selain itu, pendidikan Islam juga harus melakukan reshape or create terhadap segenap aspek di dalamnya agar selalu kontekstual terhadap tuntutan dan perubahan (Priatmoko, 2018).

\section{Tuntutan Studi Islam di Perguruan Tinggi}

Ketersediaan sumber daya manusia, sumber daya alam, dan sumber media serta informasi yang ada di perguruan tinggi terkadang mengundang banyak tuntutantuntutan dari berbagai pihak. Pihak-pihak yang terlibat tersebut menginginkan program pendidikan yang ideal dan sempurna dari segi apapun baik dari kurikulum pendidikannya, tenaga pengajar yang professional dalam bidangnya, sarana dan prasarana perguruan tinggi yang kompleks, dan lain sebagainya. Sehingga perguruan tinggi hendaknya mengupayakan dan memaksimalkan program pendidikan yang ada di perguruan tinggi. Semakin bertambahnya pengalaman dan tuntutan, seiring bertambahnya tahun maka perguruan tinggi akan terus maju dan berkualitas.

Secara khusus pengakjian islam biasanya mayoritas lebih ditonjolkan oleh perguruan tinggi ke-Islaman seperti Institut Agama Islam Negeri (IAIN), Universitas Islam Negeri (UIN), Sekolah Tinggi Agama Islam Negeri (STAIN), dan Sekolah Tinggi Agama Islam Swasta (STAIS). Dimana di dalam perguruan tinggi tersebut tidak hanya memiliki jurusan secara umum pada perguruan tinggi pada umumnya, namun juga memiliki cukup banyak jurusan keilmuan di bidang keagamaan dan keislaman seperti fakultas adab, dakwah, syari"ah, tarbiyah, dan ushuluddin. Didalam fakultas adab ada jurusan sastra Arab, dan Sejarah Kebudayaan Islam. 
Dalam fakultas Dakwah ada jurusan komunikasi dan penyiaran Islam, manajemen dakwah, bimbingan dan penyuluhan, dan jurusan pengembangan masyarakat Islam. Dalam fakultas syari"ah ada jurusan hukum keluarga Islam, Siyasah dan Jinayat, perbandingan mazhab dan hukum, dan jurusan mu"amalat. Dalam fakultas tarbiyah ada jurusan pendidikan agama Islam, Kependidikan Islam, dan Bahasa Arab. Dalam fakultas ushuluddin terdapat jurusan tafsir hadits, perbandingan agama, dan aqidah filsafat Islam. Itulah bentuk-bentuk pengorganisasian Studi Islam yang ada di Perguruan Tinggi Islam di Indonesia (M. Atho Mudzhar, 2002).

Menurut Azyumardi Azra, terdapat dua tantangan yang harus dihadapi dan sekaligus menjadi tantangan UIN/IAIN/STAIN ke depan, yaitu yang disebut sebagai harapan sosial (social expectation) dan harapan akademis (Azra, 1999).

Penyelenggaraan pendidikan di perguruan tinggi terutama pada UIN/IAIN/STAIN bertujuan untuk menghasilkan tenaga keilmuan Islam yang merupakan inti dari tenaga penggerak pendidikan, penelitian, dan pengembangan ilmu pengetahuan. Selain itu secara khusus bertujuan untuk mengembangankan kemampun dan keahlian peserta untuk menguasai bidang keilmuan Islam dan sekaligus ilmu bantu yang diperlukan dalam pengembangan ilmu pengetahuan Islam dan mengamalkannya dalam masyarakat luas. Memiliki keterampilan dan keahlian dalam bidang keilmuan Islam dan penelitian dan bidang program (konsentrasi) yang bersangkutan. Memiliki sikap ilmiah dan amal ilmiah sebagai tenaga ahli dalam keilmuan Islam.

Dengan demikian kompetensi yang harus dicapai oleh peserta (dan lulusan) perguruan tinggi yaitu: 1) penguasaan atas paradigma umum keilmuan Islam, 2) penguasaan dan keahlian dalam bidang tertentu keilmuan Islam, 3) penguasaan dan kemampuan dalam ilmuilmu bantu, 4) penguasaan dan kemampuan dalam melakukan penelitian, 5) kemampuan mengabstraksikan dan melakukan teoritis keilmuan, setidaknya dalam keahlian keilmuan konsentrasinya yaitu dalam bentuk karya akademis.

Pengetahuan tentang Islam umumnya jelas merupakan kompetensi dasar yang tidak bisa ditawar, atau mutlak adanya. Baik dari sudut ekspektasi akademis (academic expectation) keilmuan keislaman, maupun harapan sosial (sosial expectation) setiap peserta maupun lulusan perguruan tinggi harus memiliki pengetahuan umum tentang Islam. Pengalaman dan observasi baik terhadap peserta tes masuk perguruan tinggi maupun mereka yang sedang menyelesaikan program S2 maupun S3 terdapat cukup banyak di antara mereka yang memiliki pengetahuan sangat minimal tentang Islam umumnya (Azra, 2014).

Untuk keperluan tersebut, sistem pendidikan yang dilaksanakan di UIN/IAIN /STAIN/STAIS tidak lagi hanya mengajarkan ilmu-ilmu Islam tradisional saja. Pengajaran ilmu-ilmu Islam di UIN/IAIN/STAIN/STAIS diiringi pula dengan pengenalan terhadap berbagai ilmu-ilmu modern, baik ilmu-ilmu sosial maupun ilmuilmu alam. Hal tersebut juga ditegaskan oleh Amin Abdullah dalam bukunya, Ia mengatakan bahwa dalam era UIN, fakultas Syari"ah tidak boleh menolak untuk dimasuki mata kuliah baru yang mengandung muatan humanities kontemporerkontemporer dan ilmu-ilmu sosial seperti hermeneutik, cultural, dan religious studies, HAM, sensitivitas gender, filsafat ilmu, dan begitu seterusnya. Jika tidak, maka mahasiswa akan menderita ketika mereka keluar kampus dan berhadapan dengan realitas sosial kemasyarakatan dan relitas sosial keagamaan yang begitu kompleks. Begitu juga fakultas Tarbiyah, Dakwah, Adab, dan Ushuluddin. Muatan ilmu-ilmu sosial, seperti sosiologi agama dan antropologi agama serta humanities kontemporer seperti teologi pembebasan, HAM dalam Islam, gender issues, ethics, sejarah ilmu pengetahuan, filsafat ilmu pengetahuan dan begitu seterusnya harus tampak benar dalam kurikulum dan silabusnya (Amin Abdullah, 2006).

Tujuan utama dari pengenalan ini adalah terciptanya sarjana muslim yang tidak saja menguasai ilmu-ilmu agama, tetapi juga mampu menyampaikan pesan-pesan agama melalui bahasa ilmu modern. Dengan kata lain seperti dikatakan orang adalah untuk menciptakan "ulama plus". 
Lembaga Pendidikan Islam seyogyanya diarahkan untuk melahirkan sumber daya manusia memiliki kesiapan memasuki era globalisasi, era industrialisasi dan era informasi. Lulusan Perguruan Tinggi Islam diharapkan mampu hadir secara fungsional menjawab dan memecahkan problem-problem ke-ummatan, bukan menjadi trouble maker-nya. Problem keummatan begitu banyak, sangat komplek, saking kompleknya dalam menjawab tantangan dan problem tidak cukup dengan satu dimensi keilmuan saja, oleh karena itu sarjana Perguran Tinggi Islam diharapkan mampu berpikir bijak dengan mengambil dari berbagai sudut keilmuan, sehingga dapat mengambil tindakan secara bijaksana (Ikhwan, 2016).

Perubahan STAIN menjadi IAIN, atau menjadi UIN juga merupakan tuntutan akan penyelenggaraan pendidikan yang professional, berkualitas tinggi dan menawarkan banyak pilihan. Apalagi dengan sambutan arus globalisasi yang melahirkan lingkungan persaingan dan kompetisi.Sehingga IAIN dengan menjadi UIN merupakan bagian dari upaya menghadapi tantangan dan menangkap peluang. Gagasan menuju universitas bukan tidak menghadapi tantangan ataupun hambatan. Banyak hal yang diperlukan untuk menjadi lembaga pendidikan yang bagus misalnya: manajemen pendidikan, pimpinan, tenaga pendidik, staff, karyawan, mahasiswa, sarana-prasarana dan kesiapan SDM juga sangat berpengaruh untuk membangun citra yang bagus pada zaman modern sekarang ini (Aminuddin, 2019).

\section{Pengembangan Studi Islam di Perguruan Tinggi}

Dengan melihat berbagai perkembangan dan perubahan yang terjadi di dalam sistem pendidikan UIN/IAIN/STAIN, suatu hal yang pasti adalah perlunya juga perubahan dan pengembangan berbagai perangkat dan sarana pendukungnya. Salah satu sarana pendukung tersebut adalah perpustakaan. Perpustakaan UIN/IAIN/STAIN dituntut untuk melakukan berbagai pembaharuan dalam rangka memberikan respon positif terhadap perubahan dan perkembangan yang terjadi dalam sistem pendidikan.

Sebagai sebuah masyarakat modern, perpustakaan memerlukan pengaturan tentang hak dan kewajiban dalam cara menyajikan, menyimpan, menyebarkan dan menggunakan informasi dalam kegiatan pendidikan tinggi. Perpustakaan juga masih bekerja dengan prinsip-prinsip legal dan etika yang didasarkan pada tradisi cetak. Manakala teknologi digital membawa ciri-ciri baru ke dunia kepustakawanan, maka tugas pustakawan untuk memahami aturan-aturan baru yang diperlukan agar kegiatan perpustakaan tetap pada koridor hukum yang berlaku di suatu masyarakat (Hartono, 2018).

Dalam hal corak studi Islam di Perguruan Tinggi ini, Zainudin Fananie, mengatakan bahwa ada beberapa pembaharuan pemilkiran Islam di perguruan tinggi, antara lain: pertama, pembaharuan yang bersifat dan terkait erat dengan faham kemazhaban, yakni berusaha mencanggihkan warisan faham mazhab dengan menyerap unsur-unsur modern dari kebudayaan Barat. Kedua, pembaharuan yang bercorak majlisi yang nampak dalam sikap mengutamakan kesatuan pendapat dengan membentuk majlis; ketiga, pembaharuan yang bersifat kekampusan, yang didominasi oleh orientasi pemiikiran yang mandiri dan liberal yang merupakan watak kesarjanaan yang menjadi ciri khas perguruan tinggi (Fananie, 1999).

Dari beberapa uraian diatas, dapat diketahui corak pemikiran studi Islam di perguruan tinggi Islam yaitu:

a. Berbagai kajian keislaman tidak lagi terikat atau cenderung memihak pada salah satu madzhab tertentu saja.

b. Bercorak majlisi, yaitu keistimewaan orientasi ini adalah mengutamakan keseragaman dan stabilitas umat.

c. Bercorak kekampusan, Ciri-ciri dari orientasi ini adalah kehidupan kampus diwarnai oleh dominasi pemikiran yang mandiri. Corak ke kampusan harus berkembang di perguruan tinggi Islam agar mahasiswa dapat lebih aktif dalam mengemukakan pendapat. 
d. Studi Islam di Perguruan Tinggi Islam dibarengi dengan pengenalan terhadap ilmu-ilmu modern, baik ilmu sosial maupun ilmu-ilmu alam.

Adapun M. Amin Abdullah seorang yang berpengaruh dalam perguruan tinggi islam yaitu UIN. Ia menerbitkan beberapa buku-buku diantaranya dalam antologi, Studi Agama: Normativitas atau Historisitas. Amin telah mengemukakan beberapa kegelisahan tentang kesenjangan antara pendekatan normatif dan historis serta menunjukkan sering terjadinya ketegangan (tension) antara kedua pendekatan tersebut. Setelah terbitnya Dinamika Islam Kultural, terbit Islam Studies di Perguruan Tinggi: Pendekatan Integratif-Interkonektif.

Peta hubungan ilmu-ilmu keislaman dengan sumber normatifnya, al-Qur"an, dengan ilmuilmu lain dijelaskan dalam bentuk "jaring laba- laba". Substansi hubungan antara wilayah keilmuan tersebut pada dasarnya, menurutnya, harus memiliki karakteristik:

1) Integratif

Integratif yaitu bahwa pendekatan yang mengandai bahwa pendekatan kajian Islam normatif dan historis (baca: Barat) diterapkan secara bersamaan dan sintesis. Integrasi tersebut agaknya merupakan jawaban atas kegelisahan dan kritik dari masing-masing pendekatan dengan melontarkan kritik; pendukung pendekatan normatif menuduh, misalnya, sebagai reduksionisme terhadap pendekatan historis, sedangkan yang terakhir juga menuduh yang pertama sebagai pendekatan yang kaku, tertutup, dan harfiah/ literalis. Integrasi itu juga didasarkan atas kenyataan bahwa yang normatif dan historis tidaklah terpisah; yang diklaim normatif sering merupakan human construction sebagaimana yang historis sering memiliki akar-akar normatif. 2) Interkonektif (interdisipliner)

Interkonektif yaitu bahwa pendekatan-pendekatan tersebut tidaklah saling terpisah (atomistik), dipertentangkan (dikotomistik) atau meski diterapkan bersamaan, namun tidak berjalan sendiri, baik hanya model paralel atau linear. Pendekatan seharusnya bersifat sirkuler. Pendekatan normatif melalui tafsir, misalnya, diterapkan secara integratif dan interkonektif dengan ilmu-ilmu pendukungnya, seperti linguistik, sosio-linguistik sosiologis, antropologis dan kesejarahan. Begitu juga, diandaikan pendekatan ilmiah ketika diterapkan untuk mengkaji fenomena sosial kemasyarakatan sebagai ekspresi penganutnya dari penghayatan dan pengamalan kitab sucinya seperti itu tidak lah terpisah dari bagaimana teks-teks (nash) itu semula berbicara (kelak hal ini dipertegas oleh Kuntowijoyo dengan kritik epistemologisnya terhadap ilmu-ilmu sosial Barat yang ingin "didamaikan" dengan wahyu yang juga harus dianggap sebagai sumber pengetahuan). Ide tentang interkoneksi pendekatan-pendekatan itu tampak dari tawarannya dalam hal tafsir al-Qur"an yang harus dibaca dengan "at-ta`wil al,ilmi”, yaitu penafsiran al-Qur"an yang menerapkan secara interkonektif antara pendekatan bayani (eksplanatif dengan berpusat pada nash/teks sebagai sumber kebenaran utama), burhani (demonstratif dengan berpusat pada inteleksi dan penggunaan akal sebagai sumber kebenaran utama), dan irfani (gnostik yang berpusat pada kebenaran intuitif). Ide ini tentu saja tidaklah seluruhnya baru. Muhammad „Abid al-Jabiri dalam tiga buku serial kritik nalar Arabnya (Takwin al-„,Aql al-„Arabi, Bun-yat al-„,Aql al„Arabi, dan al-„,Aql as-Siyasi al- „Arabi) telah mengklafisikan tiga model epistemologi ArabIslam itu. Berbeda dengan Amin, al-Jabiri sebenarnya tidak sama sekali memaksudkan tiga model epistemologi itu dalam konteks pembacaan kitab suci. Sebagai dosen dalam filsafat Islam, al-Jabiri mengklasifikasikannya sebagai keadaan intelektualitas Arab-Islam untuk tujuan dikritik demi sebuah nahdhah (kebangkitan) Arab yang diinginkannya. Namun, menggunakan bahan-bahan yang disusun oleh orang lain (meski semula untuk tujuan yang berbeda) untuk dibangun sebuah konstruksi metodologi "baru" adalah sesuatu wajar dan harus diapresiasi dalam konteks menatap masa depan Islam yang lebih baik.

Idealnya, akal, wahyu, dan intuisi terintegrasi dan berinterkoneksi secara seimbang. Oleh karena itu, untuk mengintegrasi dan menjadikan berinterkoneksi, pendekatan-pendekatan tersebut seharusnya berjalan secara sirkuler, bukan satu arah saja.

Pandangan ini memang faktual. Sebagai contoh, kajian Kalam yang selama ini berada dalam wilayah bayani (berpusat pada nash, pembelaan/defensif-apologetik) sering kering 
dari pendekatan „,irfani karena terjebak pada debat semantik, olah rasional, demonstrasi dalil, dan sering akhirnya justru kehilangan dimensi spiritual. Begitu juga, Kalam hanya menjadi intellectual exercise yang tidak "didialogkan" dengan konteks sosiologis, seperti kemiskinan dan melemahnya etos kerja, di Indonesia secara umum dan di Kalimantan Selatan secara khusus. Atau dengan ungkapan lain, Kalam sama sekali tidak memiliki efek transformatif bagi penghayatnya. Ini adalah sebuah kesenjangan.

"Jaring laba-laba" tersebut sudah menggambarkan setidaknya: (1) al-Qur"an dan Sunnah sebagai sentral dalam kajian-kajian Islam yang integratif; (2) Tidak ada dikotomisasi ilmuilmu Islam normatif dan ilmu-ilmu lain; (3) Setelah al-Qur"an dan Sunnah, metode dan pendekatan sangat ditekankan untuk dikaji lebih awal dibandingkan disiplin-disiplin lain; (4) Pelapisan ilmu-ilmu yang harus dikaji yang terkait dengan skala prioritas. Akan tetapi, harus juga diakui, bagan itu hanya "menujukkan pintu-pintunya" dalam pengertian belum menggambarkan penyelesaian problem yang justru ditunggu-tunggu dan kini dibicarakan, yaitu bagaimana hubungan antara dua disiplin keilmuan itu pada tingkat ontologi, epistemologi, dan aksiologis dengan jelas. Islamisasi ilmu atau pengilmuan Islam adalah pilihan yang sama-sama problematic.

Selanjutnya seorang tokoh bernama M. Dawam Rahardjo mengungkapkan beberapa langkah dalam mendekolonialisasi ilmu-ilmu Barat menjadi Paradigma alQur"an. Dekolonialisasi adalah upaya "menyeterilkan" ilmu-ilmu dari kepentingan kolonialisme sebagaimana kemunculan awal ilmu-ilmu tersebut. Tapi proyek keilmuan ini seharusnya tidak diiringi dengan sikap yang sama-sama berbahayanya dalam konteks ilmiah di tubuh umat Islam, yaitu apologi. Upaya dekolonialisasi ilmu-ilmu itu juga menjadi target utama apa yang disebut sebagai "post kolonialisme". Tahap dekolonialisasi, khususnya, ilmu-ilmu sosial, menurut M. Dawam Rahardjo, adalah:

Langkah pertama, merumuskan grand theory (teori dasar). mengembangkan teori-teori pengembangan masyarakat dan perubahan sosial yang mengacu kepada ajaran Islam sendiri. Teori tersebut bisa merupakan teori dasar.

Langkah kedua, bertolak dari grand theory, dikembangkan teori tingkat menengah (middle range theory) untuk dapat merumuskan hipotesis.

Langkah ketiga, untuk mengembangkan teori besar, penelitian harus bertolak dari kritik terhadap keadaan masyarakat yang dialami sekarang, karena beberapa teori besar lahir dari kritik, seperti teori Marx sebagai kritik terhadap masyarakat kapitalis. Jadi, teori tersebut bukan menjustifikasi keadaan masyarakat yang sedang berlangsung, melainkan analisis kritis, seperti halnya teori kritis (critical theory) pada aliran Frankfurt.

Langkah keempat, teori yang dihasilkan harus dipraktekkan sehingga juga berakar dari pengalaman. Praktek sistem keuangan Islam di berbagai negara, misalnya, menghasilkan sejumlah pengalaman yang dapat dijadikan dasar bagi pengembangan ekonomi Islam.

Tidak ada pendekatan tanpa keterbatasan, sebagaimana setiap pendekatan memiliki keunggulan. Jika kita mengevaluasi pendekatan-pendekatan dalam mengkaji Islam, kita akan sampai pada simpulan tidak ada pendekatan kajian Islam yang sempurna karena realitas Islam adalah kompleks.

Pertama, pendekatan normatif yang berbasis pada telaah kitab suci al-Qur"an dan assunnah memiliki sebagaimana telah diuraikan, seperti terjadinya dikotomisasi ilmu agama yang bersumber dari wahyu danilmu umum serta hilangnya kepekaan sejarah bahwa setiap pemahaman agama, termasuk aliran-aliran, memiliki sisi kesejarahan.

Kedua, pendekatan filologis yang kaku yang menjadikan pesan agama terbatas pada teks, padahal agama di samping teks (nash), juga adalah realitas dan fenomena sosial-kesejarahan. Studi tentang al-Qur"an yang dilakukan oleh Barat, misalnya, cenderung melihat asal-usul bahasa al-Qur"an, bahasa Arab, dari rumpun bahasa Semit yang kemudian berimplikasi pada simpulan bahwa ide-ide dasar ajaran al-Qur"an adalah sinkretisasi berbagai ajaran-ajaran yang berkembang di lingkungan budaya Semit. 
Ketiga, pendekatan historis yang mengabaikan teks hanya akan melihat Islam sebagai sejarah-sejarah yang sebenarnya adalah hasil pemahaman dan praktik penganutnya dari teks al-Qur"an sebagai sumbernya. Hingga batas tertentu, pendekatan historis, sebagaimana beberapa pendekatan ilmiah, terasa reduksionis terhadap esensi Islam. IslamJ awa, misalnya, bukanlah potret sesungguhnya Islam, karena ia hanya merupakan satu varian sejarah yang berbeda dengan, misalnya, Islam di Kalimantan, Cina, Rusia, dan Timur Tengah. Memotret Islam hanya dari pendekatan sejarah menjadikan Islam terfragmentasi, terbagi menjadi kepingan-kepingan sejarah yang hingga batas tertentu diperlukan, namun bukan merupakan gambaran sesungguhnya Islam. Namun, di sisi lain, keunggulan pendekatan historis adalah karena ia dapat menjelaskan historisitas teks dan historisitas pemahaman melalui analisis sejarah: dari historical explanation (paparan sejarah; what, who, whom, when, where) hingga historical criticism (kritik sejarah; why).

Keempat, pendekatan ilmu-ilmu sosial (social sciences) melalui teori-teorinya, seperti etika Protestan dan semangat kapitalisme dalam sosiologi Weber atau teori bunuh diri (suicide) dalam sosiologi Durkheim, bisa membingkai pembacaan tingkah laku masyarakat dengan teori. Namun, generalisasi dalam pendekatan sosiologis terhadap fakta empiris tingkah laku manusia tentang agama tidak bisa menghindari terjadinya reduksionisme.

Kelima, pendekatan fenomenologis dengan cara "epoche" (melepaskan atribut), menunda keputusan dengan "pemberian tanda-kurung", dan reduksi transendental bertolak dari asumsi bahwa manifestasi kultural agama yang beragama, pada akhirnya, bisa di ureduksi kepada struktur fundamentalnya. Fenomenologis akhirnya lebih banyak mengapresiasiyang mistis (pengalaman spiritual manusia beragama yang individual dan tak terekpresikan yang dianggap oleh fenomenolog sebagai struktur fundamental) dibanding dimensi-dimensi lain Islam. W.C. Smith pernah mengatakan pemahaman seseorang terhadap agama orang lain adalah benar jika penganutnya menyatakan "ya". Model pemahaman ini didasarkan atas verstehen dan interpretive understanding terhadap pengalaman agama orang lain. Dengan cara begini, fenomenologi memiliki kelebihan karena apresiasinya terhadap orang lain yang dalam pendekatan social science justeru mengalami reduksi. Akan tetapi, dengan pendekatan fenomenologi, apalagi seperti pernyataan Smith, seorang pengkaji agama tidak bisa bersikap kritisantara pengalaman agama murni yang terekspresikan dengan kepentingan pemeluk di dalamnya, seperti temuan De Wese terhadap kepentingankepentingan politis di balik penyusunan manaqib (hagiografi) tokoh-tokoh tashawuf, suatu yang dilupakan dalam pembacaan apreasiatif fenomenologi Annemarie Schimmel dalam Mystical Dimensions of Islam.

Watak studi Islam di perguruan tinggi Islam lebih berorientasi pada penguasaan substansi materi dan penguasaan atas khazanah keilmuan keislaman, yang kemudian akan diikuti dengan pengamalan terhadap ajaran-ajaran Islam yang telah diplajari. Sedangkan watak studi Islam di Barat lebih berorientasi pada Islam sebagai realitas atau fenomena sosial saja. Metodologi yang digunakan dalam studi Islam di perguruan tinggi Islam antara lain dengan menggunakan pendekatan normatif, sosiologis, historis, filosofis, dan empiris. Untuk itu maka pendekatan studi agama di perguaruan tinggi akan tepat jika menggunakan metode sisntesis antara pendekatan kitab suci dan metode keilmuan. Yang dimaksud keilmuan disini adalah pendekatan filosofis, sosiologis, historis, fenomenologis, dan tipologis. Salah satu kelemahan pendekatan normatif, menurut Azra adalah kecenderungan melihat agama Islam sebagai agama yang ideal, yang bisa menyebabkan seorang Muslim untuk terperangkap dalam kepuasan spiritual dengan mengabaikan realitas sosial dan sejarah.

Dilihat dari kelemahan tersebut, dapat kita pahami bahwa pendekatan normatif saja tidak cukup untuk mengkaji Islam, apalagi di PTAI, yang merupakan lembaga pendidikan tinggi yang memiliki tiga ciri utama, yaitu; pendidikan, penelitian, dan pengabdian kepada masyarakat. Tentunya untuk melaksanakan tiga ciri utama tersebut tidak cukup dengan pendekatan normatif saja.

Pendekatan historis digunakan sebagai upaya untuk menelusuri asal-usul serta 
pertumbuhan pemikiran dan lembaga keagamaan melalui periode perkembangan sejarah tertentu, serta untuk memahamii peranan kekuatan yang diperlihattkan oleh agama dalam periode-periode tersebut. Pentingnya pendekatan sosiologis dalam memahami agama dapat dipahami karena banyak sekali ajaran agama yang berkaitan dengan masalah sosial. Besarnya perhatian agama terhadap masalah-masalah sosial ini selanjutnya mendorong kaum agama termasuk para intelektuual muslim di perguruan tinggi agama, memahami ilmuilmu sosial sebagai alat untuk memahami agamanya.

Pendekatan empiris dalam memahami agama adalah seperti yang dilakukan oleh Mukti Ali di IAIN, dengan melakukan penelitian agama, dan mengadakan pelatihan penelitian agama bagi intelektual muslim di perguruan tinggi agama Islam. Menurut pengamatan dan penelitian Fazlur Rahman, salah satu penyebab tidak berkembangnya disiplin keilmuan kalam khususnya atau studi-studi keislaman pada umumnya, baik dari segi materi maupun metodologi, adalah dipisahkannya dan dihindarinya pendekatan dan pemahaman filosofis dalam batang tubuh kerangka keilmuan kalam. Menurutnya disiplin ilmu filsafat dan pendekatan filosofis pada umumnya sangat membantu untuk menerobos kemacetan, bahkan jalan buntu yang dihadapi oleh ilmu-ilmu apapun.

Berfikir secara filosofis yang digunakan dalam memahami agama, dengan maksud agar hikmah, hakikat, atau inti dari ajaran agama dapat dimengerti dan dipahami secara seksama. Dari uraian tersebut dapat kita pahami bahwa pendekatan filosofis merupakan salah satu pendekatan yang harus digunakan dalam mengkaji Islam di Perguruan Tinggi Islam, selain pendekatan normatif, historis, sosiologis, dan empiris.

Integrasi dalam studi Islam di Pendidikan Tinggi Keagamaan Islam (PTKI) menjadi jawaban untuk mengurai sekelumit problematika sosial yang kerap dijumpai dalam masyarakat multikultural, seperti koeksistensi yang terganggu, tercerabutnya sendisendi toleransi, memudarnya rasa saling menghargai, serta menguatnya isu SARA. Integrasi tersebut memadukan disiplin agama, eksakta, dan sosial-humaniora dalam bentuk praksis desain kurikulum dan pembelajaran. Ilmu-ilmu keagamaan (ulūm aldīn) yang selama ini dikaji secara parsial diintegrasikan dengan disiplin ilmu-ilmu sosial modern secara holistik dan padu. Integrasi antar-disiplin keilmuan dalam studi Islam di PTKI harus terus dikembangkan demi terwujudnya sistem pendidikan Islam guna merawat peradaban. Karena tujuan pendidikan Islam bukan hanya melahirkan generasi yang pandai secara akademik, tetapi juga cerdas secara sosial, dan memiliki karakter kebinekaan. Pada akhirnya integrasi sains dan agama dalam studi di PTKI merupakan agenda besar yang tidak akan bisa berjalan tanpa kontribusi semua pihak yang terlibat di dalamnya (Rohman, Syahril, \& Fauziyati, 2018).

Menyusun dan merumuskan konsep integrasi keilmuan tentulah tidak mudah.

Apalagi berbagai upaya yang selama ini dilakukan oleh beberapa perguruan tinggi

Islam, terutama di Indonesia, dengan cara memasukkan beberapa program studi keIslaman diklaim sebagai bagian dari proses integrasi keilmuan. Merumuskan modelmodel integrasi keilmuan secara konsepsional memang tidak mudah. Hal ini terjadi karena berbagai ide dan gagasan integrasi keilmuan muncul secara sporadis baik konteks tempatnya, waktunya, maupun argumen yang melatarbelakanginya (Jamal, 2017).

Pendekatan interdisipliner dan multidisipliner sangat penting dalam studi Islam dengan beberapa alasan: Pertama, Pendekatan interdisipliner merupakan pendekatan yang sangat penting untuk digalakan apalagi jika pendekatan ini di pakai untuk memahami pesan-pesan Islam yang terkandung dalam al-Qur"an dan al-Hadits.Kedua, Pendekatan interdisipliner merupakah langkah pendekatan baru dalam rangka melakukan kontekstualisasi pesan-pesan Islam, agar pesan-pesan Islam betul-betul shalih li kulli zaman wa al-makan (Rohmatika, 2019).

Moderasi kurikulum di tiga Perguruan Tinggi Islam di Indonesia UIN Syarif Hidayatullah Jakarta, IAIN Surakarta, dan STAIN Kediri dalam deradikalisasi agama mempunyai kemiripan. 
Membenahi sistem kurikulum dalam pendidikan, justru lebih berdaya guna dalam pencegahan dan penangkalan radikalisme. Terdapat delapan moderasi kurikulum tersebut sebagai berikut: 1) Integrasi dan internalisasi keilmuan, yaitu mengembangkan dan mengintegrasikan aspek keislaman, keilmuan, kemanusiaan, dan keindonesiaan, dengan cara reintegrasi keilmuan pada tingkat ontologi, epistimologi, dan aksiologi, sehingga tidak ada lagi dikotomi ilmu umum dan ilmu agama; 2) Pengetahuan teologi rahmatan lil"alamin, yaitu menampilkan ciri Islam yang damai, penuh kasih, anti kekerasan, dan menyapa semua makhluk terlepas dari perbedaan asal usul agama dan keyakinan; 3) Deradikalisasi melalui penguatan kearifan lokal Jawa, yaitu mengharmonisasikan antara nilai-nilai Jawa dengan nilainilai Islam. Salah satu ciri khas kebudayaan Jawa adalah penekanannya yang menonjol pada aspek keselarasan atau harmoni; 4) Membangun kurikulum anti radikalisme. Pergururan Tinggi Islam di Indonesia telah berhasil mengembangkan misi untuk menyebarkan moderasi dan toleransi serta aplikasinya dalam realitas kehidupan; 5) Evaluasi pembelajaran yang berorientasi multicultural; 6) Program Pendampingan Pengembangan Kepribadian Muslim Integral (P2KMI). Lembaga pendidikan tinggi formal tidak hanya berfungsi sebagai lembaga transfer ilmu pengetahuan dan pengembangan saja, melainkan juga sebagai tempat untuk pembentukan akhlak yang mulia (akhlaqul karimah); 7) Integrasi nilai Pluralitas dalam Kurikulum. Dalam lingkup perguruan tinggi, pengintegrasian suatu nilai dapat dilakukan dengan cara inkulturasi, yaitu keseluruhan proses pengintegrasian nilaisikap, pandangan, keyakinan ke dalam proses pendidikan, baik dalam materi, metode, dan evaluasi pendidikan. Inkulturasi ini mengisyaratkan pendidikan karakter diimplementasikan sebagai learning experience, peserta didik langsung memahami dan mengalami sendiri nilainilai pluralitas yang diharapkan, yakni kecerdasan plus karakter yang difokuskan pada hard skill dan soft skill; 8) Metode pembelajaran yang multikulturalisme yaitu metode yang dipakai perguruan tinggi melalui diskusi (Ekawati, Suparta, \& Sirin, 2018).

\section{Simpulan}

Berdasarkan materi dalam pembahasan makalah ini dapat disimpulkan bahwa perguruan tinggi yang paling kompleks dalam memberikan studi islam bagi masyarakat khususnya pada mahasiswa yaitu perguruan tinggi islam, seperti UIN/ IAIN/STAIN/STAIS. Setiap fakultas dan jurusan yang ada diperguruan ke-Islaman ini sudah menerapkan kajian-kajian ke-Islaman di samping dari mata kuliah wajib program studi. Pengenalan atau oreantasi studi keislaman di perguruan tinggi Indonesia tidak hanya sebatas di negara Indonesia saja tetapi juga meneliti pada dunia Timur dan Barat. Pendekatan yang digunakan dalam mengkaji islam pada perguruan tinggi di Indonesia yaitu menggunakan lebih dari satu pendekatan yaitu menggunakan berbagai pendekatan seperti normative, historis, sosiologis, empiris, filosofis, Integratif, Interkonektif, fenomenologis, dan tipologis. 


\section{Daftar Pustaka}

Amin Abdullah. (2006). Islamic Studies di Perguruan Tinggi: Pendekatan IntegratifInterkonektif. Yogyakarta: Pustaka Pelajar.

Aminuddin, M. Y. (2019). Perubahan Status Kelembagaan pada Perguruan Tinggi Agama Islam dalam Menghadapi Tantangan dan Peluang Pendidikan Islam di

Indonesia. Ta'lim: Jurnal Studi Pendidikan Islam, 2(1).

Azra, A. (1999). Pendidikan Islam: Tradisi dan Modernisasi Menuju Milenium Baru. Jakarta: Logos.

Azra, A. (2014). Pendidikan Islam: Tradisi dan Modernisasi di Tengan Tantangan Milenium III. Jakarta: Kencana.

Anam, S. dkk. 2021. Bunga Rampai Pemikiran Pendidikan Islam. Yogyakarta: Semesta Aksara.

Ekawati, E., Suparta, M., \& Sirin, K. (2018). Moderasi Kurikulum Perguruan Tinggi Islam Dalam Deradikalisasi Agama Di Indonesia. Istiqro, 16(01).

Fananie, Z. (1999). Pengembangan Model Studi Islam di Indonesia, dalam Studi Islam Asia Tenggara. Surakarta: UNMUH Surakarta.

Hartono, H. (2018). Strategi Pengembangan Perpustakaan Digital Dalam Membangun Aksesibilitas Informasi: Sebuah kajian teoritis pada Perpustakaan Perguruan Tinggi Islam di Indonesia. UNILIB: Jurnal Perpustakaan, 8(1).

Husna, N. 2020. Analisis Wacana Kebijakan Pendidikan (Konsep dan Implementasi). Semarang: CV. Pilar Nusantara.

Ikhwan, A. (2016). Perguruan Tinggi Islam dan Integrasi Keilmuan Islam. At-Tajdid: Jurnal Ilmu Tarbiyah, 5(2).

Jamal, N. (2017). Model-Model Integrasi Keilmuan Perguruan Tinggi Keagamaan Islam. KABILAH: Journal of Social Community, 2(1).

Kurniasih, A. (2013). Pendekatan Studi Islam di Perguruan Tinggi Islam. Jurnal AsSalam, 3(1).

M. Atho Mudzhar. (2002). Pendekatan Studi Islam dalam Teori dan Praktek. Yogyakarta: Pustaka Pelajar.

Priatmoko, S. (2018). Memperkuat Eksistensi pendidikan Islam di era 4.0. TA’LIM: Jurnal Studi Pendidikan Islam, 1(2).

Rohman, M., Syahril, S., \& Fauziyati, D. (2018). Masa Depan Studi Islam Di Pendidikan Tinggi Keagamaan Islam (Sebuah Tinjauan Filosofis-Yuridis). Cendekia: Jurnal Kependidikan Dan Kemasyarakatan, 16(2).

Rohmatika, R. V. (2019). Pendekatan Interdisipliner dan Multidisipliner Dalam Studi Islam. Al-Adyan: Jurnal Studi Lintas Agama, 14(1).

Sarwadi, Islamic Boarding School and Community Empowerment, (International Journal of Education and Learning, Vol. 1, Issue 2, 2019).

Wardani. (2016). Agenda Pengembangan Studi Islam di Perguruan Tinggi: Mempertimbangkan Berbagai Tawaran Model Integrasi Ilmu. Khazanah Jurnal Studi Islam Dan Humaniora. 